\title{
Studi Analisis Sambungan Semi Rigid Balok - Kolom Baja Dengan Modifikasi Friction Damper Dengan Metode Elemen Hingga
}

\author{
Susanto Hari Asmoro ${ }^{1, *}$, Budi Suswanto ${ }^{1}$ \\ Departemen Teknik Sipil, Institut Teknologi Sepuluh Nopember, Surabaya ${ }^{1}$ \\ Koresponden*, Email: susantohariasmoro.sha@gmail.com
}

\begin{tabular}{lr}
\hline & Info Artikel \\
\hline Diajukan & 28 Juli 2019 \\
Diperbaiki & 2 Agustus 2019 \\
Disetujui & 7 Agustus 2019
\end{tabular}

\begin{abstract}
Beam and column connections are one of the elements in steel frame structure that are important in the design of earthquake resistant building construction. The semi-rigid connection regulated in the regulation allows connection of the structure to experience a slight rotation. Selection of the right connection is very necessary to ensure the occurrence of plastic joints in the beam area. This study discusses the behavior of T-Stub joint type steel connections equipped with friction dampers when given cyclic loads using software based on ABAQUS 6.14. This study will do modeling which then results will be compared from moment - rotation, rotational stiffness value and failure mode using software based on ABAQUS 6.14. The modeling used I-Shaped welded plate for beam dimensions $135 \times 270 \times 6.6 \times 10.2 \mathrm{~mm}$ and column dimensions $260 \times 200 \times 9 \times 15 \mathrm{~mm}$, and column stiffness thickness $10.2 \mathrm{~mm}$. The modelling was made in four types. Two type modelling for verification of previous research and the other two modelling are another modified connection. results of the modeling above when compared with the results of the experiments used do not have a significant difference ductility, Modelling with Hauch and Ribs more ductile better than modelling no Hauch and Ribs in connection. The most effective connection modelling was connection with equipped stifener like Hauch and Ribs. It is expected that all beam-column joint modeling with equipped friction damper can be used in earthquake resistant structures
\end{abstract}

Keywords: friction damper, cyclic loading, T-stub, finite element method, steel connection

Kata kunci: friction damper, pembebanan siklik, $T$-stub, finite element method, sambungan baja
Abstrak

Sambungan balok dan kolom merupakan salah satu elemen dalam struktur rangka baja yang penting dalam desain konstruksi bangunan tahan gempa. Sambungan semi rigid yang diatur dalam peraturan memperbolehkan sambungan struktur untuk mengalami sedikit rotasi. Pemodelan yang digunakan welded plate I-Shaped untuk dimensi balok $135 \times 270 \times$ $6.6 \times 10.2 \mathrm{~mm}$ dan dimensi kolom $260 \times 200 \times 9 \times 15 \mathrm{~mm}$, ketebalan pengaku kolom 10.2 $\mathrm{mm}$. Variasi spesimen dibuat sebanyak empat jenis. Dua untuk verifikasi penelitian sebelumnya dan dua lainnya merupakan sambungan modifikasi. Hasil dari studi spesimen dan pemodelan memiliki selisih yang tidak terlalu signifikan. Ditinjau dari nilai daktilitasnya sambungan dengan tambahan hauch dan ribs lebih daktail bila dibandingan dengan dua model lainnya. Dari semua variasi pemodelan sambungan, sambungan yang dilangkapi dengan Hauch dan Ribs memiliki performa lebih baik. Dari semua pemodelan sambungan balok - kolom yang dilengkapi dengan friction damper diharapkan dapat digunakan pada struktur yang tahan gempa.

\section{Pendahuluan}

Kebutuhan akan bangunan tahan gempa saat ini semakin tinggi khusunya pada daerah dengan tingkat resiko gempa yang tinggi seperti wilayah di Indonesia. Indonesia merupakan negara dengan aktivitas kegempaan yang sangat tinggi. Menurut United States Geological Survey - National Earthquake Information Center (USGS - NEIC), tercatat untuk wilayah Kepulauan Indonesia dalam rentang waktu antara tahun 1973 - 2009 terjadi 8.260 kejadian gempa dengan magnituda $\mathrm{M}>5,0 \mathrm{SR}[1]$.

Pada Struktur baja sambungan merupakan titik kritis akan terjadinya awal kegagalan struktur akibat gempa. Kegagalan desain sambungan serta besarnya ketidakcocokan antara perilaku yang dianalisis dan perilaku aktual, akan membuat sambungan memiliki keterbatasan kemampuan dalam menerima beban[2]. Sambungan balok dan kolom juga merupakan area yang dapat direncanakan untuk dapat semaksimal mungkin dapat mendisipasi energi gempa. Pada perencanaan sambungan balok dan kolom Full Strength pada umumnya direncanakan untuk terjadi leleh pada ujung balok tanpa mempertimbangkan efisiensi penggunaan bahan[3].

Pada saat ini, Banyak penelitian berbasis angka tentang penggunaan sambungan baja Partial Strength berdasarkan karakteristik perilaku sambungan monotonic yang diberi beban siklik, baik secara teoritis maupun numerik. Meskipun sudah banyak penelitian dilakukan tetapi masih ada beberapa 
masalah yang perlu dilakukan penelitian lanjutan, seperti karakterisasi disipasi energi yang dihasilkan oleh sambungan, penelitian tentang pengembangan jenis sambungan baru yang dapat mendisipasi energi, atau studi kelayakan tentang penggantian sambungan setelah peristiwa seis$\operatorname{mik}[4]$.

Dari latar belakang yang dirangkum secara singkat di atas, dalam rangka mengatasi kelemahan desain konvensional khususnya yang sering terjadi pada sambungan balok dan kolom maka penelitian ini bertujuan untuk mengembangkan srategi desain sambungan Partial Strength dengan menggunakan T-Stub yang dilengkapi dengan friction damping. Penelitian yang dilakukan Piluso, dkk, yang bertujuan untuk membuat pemodelan sambungan yang dilengkapi dengan redaman berupa gesekan antar pelat dan diaplikasikan pada struktur baja agar mampu bertahan saat terjadi peristiwa seismik, tanpa adanya kerusakan struktur yang ditimbulkan khususnya pada kejadian gempa bumi yang langka sekalipun dengan bantuan program ABAQUS 6.14 .

Penelitian ini nantinya juga mempertimbangkan adanya penggunaan tambahan stiffner, supplementary web, Ribs serta haunch pada variasi pemodelannya disetiap sambungan balok dan kolom. Untuk parameter lain dari tambahan stiffner, supplementary web, Ribs serta haunch pada variasi pemodelannya disetiap sambungan balok dan kolom sesuai dengan experiment yang dilakukan oleh Piluso, dkk. Dengan adanya penelitian ini, diharapkan dapat mengetahui konfigurasi mode variasi pemodelan sambungan balokkolom baja semi rigid/partial strength tertentu yang dapat menghasilkan performa struktur baja tahan gempa yang paling baik dan memenuhi syarat baik kuat maupun daktail pada bangunan untuk daerah gempa kuat.

\section{Tinjauan Pustaka}

Fungsi sambungan adalah mengalihkan gaya momen internal dari satu komponen struktur ke komponen lain sehingga pembebanan dapat diteruskan ke pondasi[5]. Menurut LRFD-A.2.2 jenis sambungan yang dipakai pada konstruksi baja dibedakan menjadi 3 (tiga) tipe:

1. Tipe terkekang penuh (fully restrained / FR)

Sambungan yang memiliki kontiunitas penuh sehingga sudut pertemuan antara batang-batang tidak berubah, yakni pengekangan rotasi sekitar $90 \%$ atau lebih dari yang diperlukan untuk mencegah perubahan sudut.

2. Tipe rangka sederhana (partially restrained / PR)

Keadaan ini terjadi jika kekangan rotasi pada ujungujung batang dibuat sekecil mungkin. Biasanya rangka sederhana dianggap terjadi jika sudut awal antara batang -batang yang berpotongan dapat berubah sampai $80 \%$ atau lebih dari jumlah perubahan sudut yang secara teoritis jika digunakan sambungan berengsel bebas.

3. Tipe Rangka Setengah Kaku

Rangka setengah kaku terjadi jika kekangan rotasi kirakira antara 20\% hingga 90\% dari yang diperlukan untuk mencegah perubahan sudut relatif.

Pada umumnya, kurva momen-rotasi dari sebuah sambungan dapat memberikan beberapa sifat atau karakteristik seperti kekakuan dari sebuah sambungan diidentifikasi dari kemiringan kurva, perilaku sambungan pada umumnya adalah non-linier, dimana kekakuan menurun sedangkan rotasi meningkat. Secara teori, kekakuan awal mempunyai angka yang sama dengan kekakuan setelah dibebani, kekakuan dari titik kumpul adalah indikasi dari nilai momen kapasitas yang dapat diambil dari nilai tertinggi pada kurva momen-rotasi. Pada Gambar 1, daktilitas meningkat seiring meningkatnya rotasi. Daktilitas dari sambungan adalah indikasi dari kapasitas rotasi yang didapat dari titik kumpul sebelum terjadi kehilangan kekuatan secara signifikan. Sebuah sambungan dapat dinyatakan ductile (elastis) jika memenuhi syarat bahwa rotasi yang terjadi lebih besar dari 0.03 radians. Pada Tabel 1 juga dimodelkan beberapa tipe sambungan yang meliputi, simple connection, rigid dan semi-rigid.

\section{T-Stub pada sambungan kolom dan balok}

$T$-Stub terbentuk dari potongan setengah profil baja I. Bagian sayap dari T-Stub di baut dan bagian badan dari $T$ Stub dikenakan kekuatan Tarik atau tekan (gambar 2). Ada dua mekanisme kegagalan dari T-Stub, yaitu kegagalan akibat dari ketebalan T-stub dan kegagalan dari sayap[6]. Pada penelitian yang dilakukan oleh Piluso, dkk, (T-stub yang terletak pada sayap bagian atas pada balok dapat dijadikan sebagai pusat rotasi yang bertujuan untuk mencegah kerusakan elemen sambungan lain dan ketika bagian sayap bawah pada balok dipasang friction damper dengan tumpuannya terletak pada $T$-Stub, menghasilkan kapasitas rotasi dan disipasi energi pada sambungan tersebut.

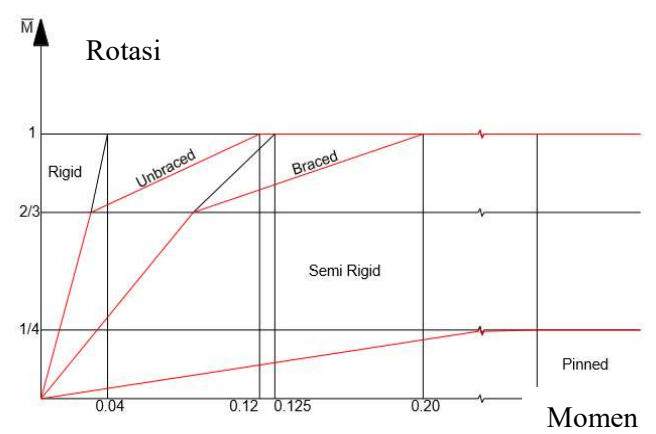

Gambar 1. Kurva momen - rotasi (M-Ø) 
Tabel 1. Tipe Model Sambungan

\begin{tabular}{|c|c|c|c|}
\hline $\begin{array}{c}\text { Momen of } \\
\text { global }\end{array}$ & \multicolumn{3}{|c|}{ Classification of joint } \\
\hline Elastic & $\begin{array}{l}\text { Nominally } \\
\text { pinned }\end{array}$ & rigid & semi-rigid \\
\hline rigid-plastic & $\begin{array}{l}\text { Nominally } \\
\text { pinned }\end{array}$ & $\begin{array}{l}\text { full- } \\
\text { strength }\end{array}$ & partial-strength \\
\hline elastic-plastic & $\begin{array}{l}\text { Nominally } \\
\text { pinned }\end{array}$ & $\begin{array}{l}\text { rigid and } \\
\text { full- } \\
\text { strength }\end{array}$ & $\begin{array}{l}\text { semi rigid and partial } \\
\text { strength semi rigid and full } \\
\text { strength rigid and partial } \\
\text { strength }\end{array}$ \\
\hline $\begin{array}{c}\text { Type of joint } \\
\text { model }\end{array}$ & simple & continuous & semi-continuous \\
\hline
\end{tabular}

Sumber: Latour, Piluso, et al, 2018[15]

Terdapat beberapa macam kegagalan pada baut dengan sistem sambungan T-Stub (Gambar 2)[7]. Pada mekanisme kegagalan yang pertama yakni kegagalan yang timbul dengan terdapat empat sendi plastis.

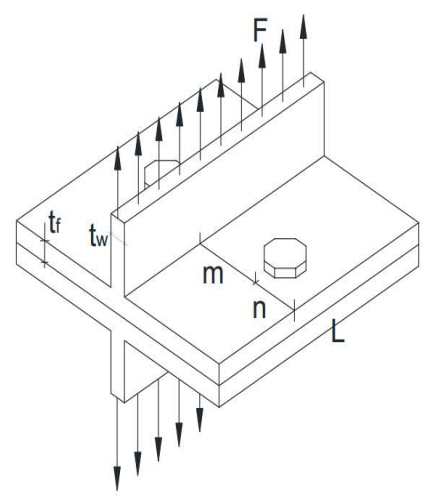

Gambar 2. T-Stub Pada Sambungan Balok-Kolom

Dua terletak pada ujung baut, yang disebabkan oleh bending momen akibat dari gaya Tarik/force $(\mathrm{F})$ (persamaan 1). Pada sisi sambungan sayap dan badan tetap dalam keadaan plastis. Pada mekanisme kegagalan yang kedua adalah terdapat dua sendi plastis yang terletak pada sambungan sayap dan badan serta rusaknya dari baut sebagai pengikat sambungan (persamaan 2). Pada mekanisme kegagalan yang ketiga yakni adanya kegagalan pada sambungan baut. Sehingga pada mekanisme ini tidak terdapat kekuatan Tarik/force (F), sehingga sambungan plat benar dalam keadaan terlepas (persamaan 3)[8].

$$
\begin{aligned}
& F_{1 . R d}=\frac{4 M_{f . R d}}{m} \\
& F_{2 . R d}=\frac{2 M_{f . R d}+2 B_{R d} n}{m+n} \\
& F_{3 . R d}=2 B_{R d} .
\end{aligned}
$$

\section{Pengaruh Sistem Friction dampers Terhadap Beban Siklik}

Redaman adalah suatu proses dimana sistem struktur mendisipasi dan menyerap energi yang masuk ke dalam bangunan dari eksitasi eksternal. Karena itu peredam (damper) mengurangi penambahan energi regangan dan respon dari sistem, terutama kondisi dimana mendekati resonansi dimana peredam mengontrol respon. Besarnya nilai redaman tergantung dari beberapa faktor seperti amplitudo getaran, material konstruksi, periode getaran, mode shapes, dan konfigurasi struktur[9].

Ada beberapa jenis perangkat kontrol pasif dan peredam. Friction dampers pasif menggunakan gesekan Coulomb untuk mendisipasi energi yang masuk akibat gempa. Alat redaman ini telah digunakan secara luas dalam berbagai proyek perkuatan di seluruh dunia, karena biayanya yang rendah dan kinerja yang baik. Selain itu, Passive dampers adalah bentuk yang paling lama dan umum digunakan. Passive dampers biasanya ditempatkan pada cross bracing diantara dua lantai yang berdekatan. Passive dampers menggunakan perpindahan dari lantai untuk menghasilkan gaya redaman pada bangunan.

Tidak seperti perangkat aktif dan semi-aktif, perangkat pasif tidak dapat merubah sifat redamannya berdasarkan respon dari struktur dan karena itu tidak memerlukan sumber energi listrik atau kontrol algoritma untuk beroperasi. Tanpa peralatan sensor atau komputasi, perangkat pasif umumnya yang paling ekonomis dan paling banyak digunakan. Sejak awal tahun 1970 berbagai jenis perangkat disipasi telah diuji dan digunakan. Perangkat ini dapat dikelompokkan menjadi tiga kategori: peredam viskos dan viskoelastik (viscous and viscoelastic dampers), peredam metalik (metalic dampers), dan peredam gesekan (friction dampers)[10].

Dengan menggunakan bracing maka defleksi bangunan berkurang seiring dengan meningkatnya kekakuan tetapi sebaliknya gaya geser dasar menjadi lebih besar karena kekakuan bangunan yang meningkat[11]. Selain itu dengan adanya penempatan friction damper pada sambungan sambungan balok dan kolom rangka baja baik desain Momen Resisting Frames dapat mendisipasi energi gempa lebih besar serta mengurangi kerusakan dari elemen-elemen sendi plastis pada struktur baja khusunya pada balok, sehingga retrofit akibat dari gempa yang berulang tidak banyak diperlukan. Permukaan pelat bantalan gesekan juga merupakan faktor penting dalam mendisipasi energi gempa terutama yang mempunyai nilai koefisien gesekan yang tinggi. Dengan nilai koefisien gesekan yang tinggi dapat mengurangi dimensi ukuran dari pelat bantalan gesekan[13]. Pada penelitian yang dilakukan oleh Piluso, dkk dengan tujuan untuk mengamati adanya lima jenis permukaan yang 
berbeda pada gesekan pelat. Menghasilkan nilai koefisien gesekan statis dan dinamis pada setiap jenis bantalan redaman (Tabel 2).

Tabel 2. Nilai Koefisien Gesekan Spesimen

\begin{tabular}{ccc}
\hline Interface & $\mu$ static & $\mu$ dynamic \\
\hline Steel on Steel & 0.173 & 0.351 \\
Brass on Steel & 0.097 & 0.200 \\
M0 on Steel & 0.254 & 0.254 \\
M1 on Steel & 0.201 & 0.201 \\
M2 on Steel & 0.158 & 0.180 \\
\hline Sumber: Latour, Piluso, et al, 2018[15]
\end{tabular}

\section{Metode}

Pemodelan dilakukan dengan membuat sambungan balok-kolom lengkap dengan friction damping dengan menggunakan alat bantu software Abaqus 6.13. Model ini dibuat berdasarkan penelitian yang dilakukan oleh Latour, Piluso, dan Rizzano[15], yang mengacu pada spesimen sambungan balok dan kolom yang dilengkapi dengan single friction damping dan T-Stub tanpa haunch. Adapun set-up test yang digunakan dalam penelitian tersebut seperti yang terlihat pada Gambar 3 dan 4. Set-up tes ini akan kembali dimodelkan dalam penelitian ini sebagai dasar untuk pemodelan berikutnya. Pada analisa dengan program bantu ABAQUS, sambungan dimodelkan sebagai berikut:

a. Sambungan $T$-Stub dimodelkan dengan dua pelat terpisah yang disambung dengan baut, dalam ABAQUS sambungan ini dinamakan Tie-constrain.

b. Tipe kontak antara baut dengan pelat dimodelkan dengan tipe friction pada program ABAQUS pada modul interaction

c. Sambungan profil $T-S t u b$ dan L-Stub ke balok dimodelkan menggunakan surface control pada program ABAQUS

d. Mur dimodelkan langsung menyatu dengan baut

e. Pemodelan kontak antara baut dengan pelat berupa gesekan

f. Bantalan redaman/Pad tidak dimodelkan hanya saja permukaan pelat $T$-Stub atau $L$-Stub diberikan hard contact dengan diberikan koefisien gesekan sesuai dengan penelitian experimental Piluso.

\section{Material Properties:}

Perkiraan dimensi awal dari elemen eleman struktur pada gedung, penentuan bahan, dan material struktur, dan merencanakan dimensi profil yang akan digunakan.

$$
\begin{array}{ll}
\text { Profil Kolom } & : \text { Profil HEB } 200(\mathrm{BJ} 41) \\
& : \text { fy }=250 \mathrm{Mpa} ; \mathrm{fu}=410 \mathrm{Mpa} \\
\text { Profil Balok } & : \text { Profil IPE 270 }(\mathrm{BJ} 41) \\
& : \text { fy }=250 \mathrm{Mpa} ; \mathrm{fu}=410 \mathrm{Mpa}
\end{array}
$$

Baut : Baut Mutu Tinggi

$$
\text { : fy }=995 \mathrm{Mpa} ; \mathrm{fu}=1160 \mathrm{Mpa}
$$

Profil T-stub, L-stub, Stiffener, Supplementary Web (BJ 41)

$$
: \text { fy }=250 \mathrm{Mpa} ; \mathrm{fu}=410 \mathrm{Mpa}
$$

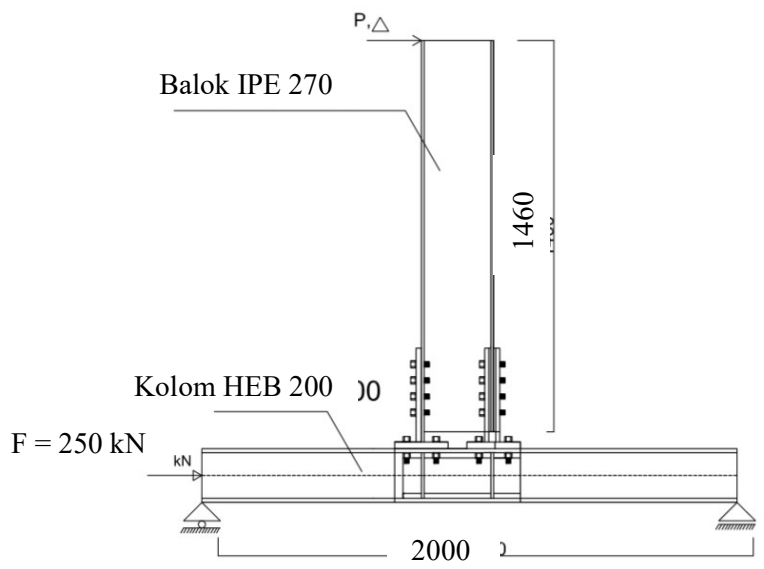

Gambar 3. Variasi sambungan TSJ-1

Sumber: Pemodelan Penelitian

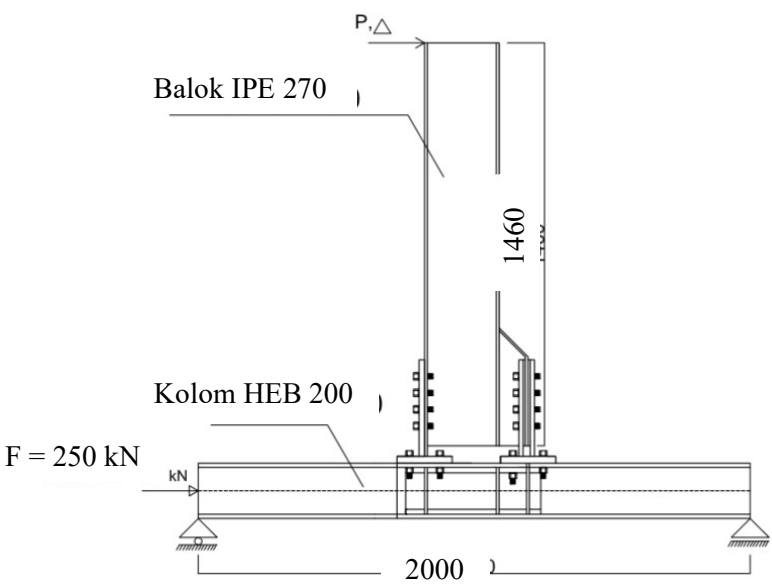

Gambar 4. Variasi sambungan TSJ-H

Sumber: Pemodelan Penelitian

\section{Pembebanan}

Pembebanan dilakukan berdasarkan penelitian yang dilakukan Latour, Piluso, dan Rizzano dalam jurnal Experimental analysis of beam-to-column joints equipped with sprayed aluminium friction dampers di tahun 2018[15]. Adapun pembebanan yang diberikan secara aktuator hidrolik dengan dua cara berbeda. Cara pertama dengan penerapan under force control, yaitu dengan memberikan beban aksial pada kolom sebesar 30\% dari beban ultimatenya. Kedua pembebanan akuator hidrolik digunakan untuk mengontrol under displacement pada ujung balok dari keadaan semula agar mendapatkan perpindahan yang direncanakan. Untuk menghindari adanya tekuk lateral akibat torsi pada balok, 
maka digunakan rangka baja yang dirancang secara horisontal sebagai penjepit dari balok yang diuji agar tidak terjadi perpindahan lateral. Pembebanan didefinisikan sebagai simpangan sudut yang terjadi sesuai dengan peraturan pengujian yang terdapat pada AISC.

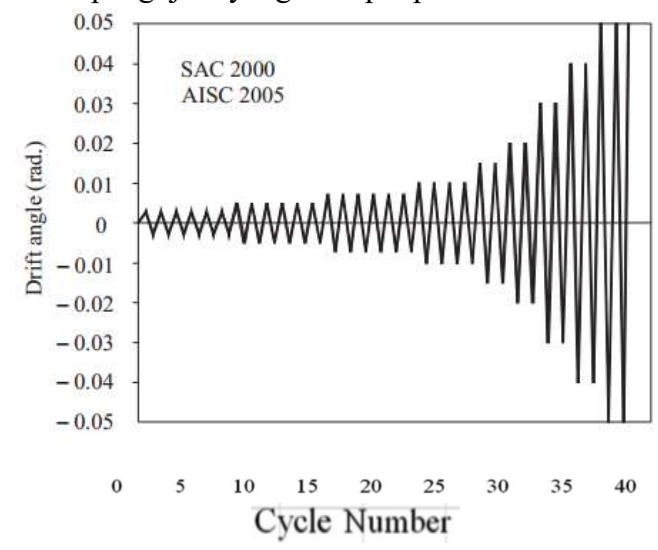

Gambar 5. Sistem Pembebanan

\section{Validasi Hasil Pembebanan:}

Kontrol terhadap pemodelan dilakukan dengan cara perbandingan terhadap hasil penelitian yang telah dilakukan sebelumnya, dengan cara pemodelan dengan program abaqus yang serupa dengan penelitian Latour, Piluso, dan Rizzano pada tahun 2018[15], pada specimen TSJ-SA300-320CYC12 dan TSJ-SA300-320-CYC13. Seperti yang diharapkan, atas dasar kriteria desain yang dipakai, di semua pengujian eksperimental belum ada kerusakan komponen sambungan yang signifikan, tetapi kerusakan hanya terjadi pada pemakaian bantalan gesekan. Pada nilai kekuatan yang rendah, sambungan menunjukkan perilaku elastis yang ditandai dengan kekakuan awal yang tinggi. Khususnya, dalam kasus TS-H-SA300-260-CYC13 saat awal terjadi kekakuan lebih tinggi karena adanya peningkatan momen akibat dari pemakaian haunch. Ketika tekanan terjadi pada ujung balok kantilever mempunyai nilai yang sama dengan besar nilai rencana momen lentur dibagi dengan panjang balok, pada saat ini mulai terjadi slippage peredam gesekan (Gambar 17-18). Setelah selip pertama, respons histeresis menandakan siklus untuk semua loading/unloading yang mendekati bentuk jajaran genjang dengan sedikit perubahan penurunan karena jumlah siklus pembebanan yang meningkat dari awal (Gambar 19).

Ciri yang paling penting dari hasil penelitian adalah sambungan dengan friction damper hal itu mampu memberikan kapasitas tinggi disipasi dan memiliki nilai rotasi yang sesuai dengan peraturan yang tertera pada Eurocode 8 untuk kerangka yang memiliki daktilitas tinggi. Selanjutnya, sangat penting untuk digaris bawahi pada penelitian didapatkan hasil kekuatan lentur balok yang lebih besar dari nilai resistensi plastis dari sambungan balok, sehingga penelitian diperoleh hasil tanpa mengakibatkan kerusakan pada ujung balok.

\section{Modifikasi Pemodelan}

Pemodelan serupa dilakukan kembali dengan beberapa perubahan dan modifikasi, sehingga menjadi langkah selanjutnya dalam pengerjaan keseluruhan penelitian ini. Tabel 3 adalah rencana Identifikasi Material pemodelan Friction damper yang diterapkan pada sambungan balok kolom dengan variasi sambungan yang berbeda

Tabel 3. Identifikasi Material

\begin{tabular}{|c|c|c|c|c|c|c|c|c|}
\hline \multirow{2}{*}{ Jenis elemen } & \multirow{2}{*}{ Profil } & \multirow{2}{*}{$\begin{array}{c}\text { Fy } \\
(\mathrm{Mpa})\end{array}$} & \multirow{2}{*}{$\begin{array}{c}\mathrm{fu} \\
(\mathrm{Mpa})\end{array}$} & \multicolumn{5}{|c|}{ Ukuran Section (mm) } \\
\hline & & & & b & $\mathrm{h}$ & tw & tf & $\mathrm{t}$ \\
\hline Kolom & HEB & 250 & 410 & 200 & 500 & 10 & 16 & - \\
\hline Balok Atas & IPE & 250 & 410 & 199 & 446 & 8 & 12 & - \\
\hline Stiffner & Plate & 250 & 410 & 91 & 182 & - & - & 10 \\
\hline T-Stub & $\mathrm{T}$ & 250 & 410 & 200 & 375 & 20 & 25 & 10.2 \\
\hline Internal angel & $\mathrm{L}$ & 250 & 410 & 200 & 375 & 20 & 25 & 10.2 \\
\hline $\begin{array}{l}\text { External } \\
\text { angel } \\
\text { Suplementary }\end{array}$ & $\mathrm{L}$ & 250 & 410 & 200 & 375 & 20 & 25 & 10.2 \\
\hline web plate & Plate & 250 & 410 & 91 & 114 & - & - & 10 \\
\hline Ribs & Plate & 250 & 410 & - & - & - & - & 6.6 \\
\hline
\end{tabular}

Sumber: Latour, Piluso, et al, 2018 [15]

\section{Karakteristik Model}

Spesimen yang akan dimodelkan terdiri dari dua spesimen (TSJ-1 dan TSJ-H) sebagai verifikasi penelitian Piluso dkk, serta dua pemodelan berikutnya adalah hasil modifikasi sambungan dua pemodelan sambungan sebelumnya (TSJ-3 dan TSJ-H) (Gambar 6 dan 7).

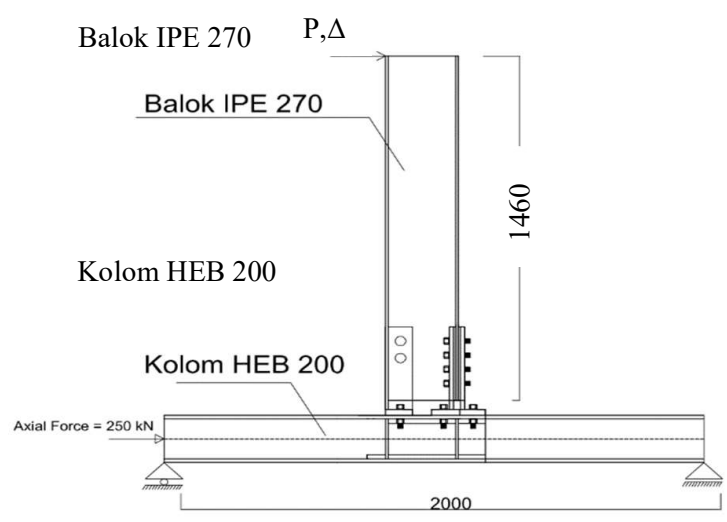

Gambar 6. Variasi sambungan TSJ-3

\section{Analisa Metode elemen Hingga}

Analisa metode elemen hingga akan dilakukan untuk memodelkan sambungan balok dan kolom yang dilengkapi dengan friction damping dalam bentuk 3 dimensi. Dalam analisa ini juga akan dilihat mekanisme sendi plastis dan kerusakan yang terjadi pada elemen. Sehingga gambaran dari 
perilaku dan kemampuan elemen dalam menerima beban dapat diketahui. Analisa metode elemen hingga ini dilakukan dengan program bantu ABAQUS. Berikut ini merupakan prosesnya sebagai berikut:

1. Analisa Kapasitas Friction damper pada sambungan

Kemampuan Friction damper pada sambungan sistem rangka dalam menerima beban yang didapatkan setelah melakukan pembebanan siklik, mulai dari pembebanan pertama, saat mencapai kekuatan leleh maupun kekuatan ultimate.

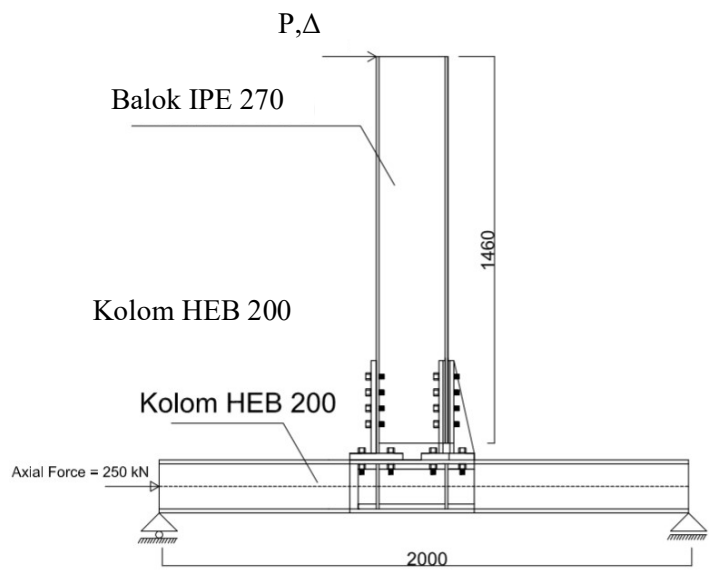

Gambar 7. Variasi sambungan TSJ-R

2. Kurva Histeresis

Hasil analisa numerik yang ditampilkan dalam kurva beban-displacement akan ditampilkan data yang didapatkan selama proses pembebanan berlangsung, khususnya pembebanan siklik. Kurva ini akan memperlihatkan kenaikan atau penurunan displacement seiring dengan pembebanan yang dikenakan pada sambungan yang dimodifikasi Friction damper pada sambungan.

3. Perilaku Boundary Elemen

Efek yang dihasilkan pada portal di sekitar sambungan balok - kolom yang dimodifikasi Friction berupa bentuk dan besarnya deformasi.

4. Daktilitas

Hubungan antara simpangan ultimate dengan simpangan waktu leleh awal. Dalam setiap varian perilaku yang dikenakan pada sambungan balok - kolom yang dimodifikasi Friction damper, akan diambil nilai tegangan dan regangan dan diambil pada tempat yang sama, sehingga dapat menghasilkan nilai yang valid.

5. Pola Kegagalan sambungan balok - kolom yang dimodifikasi dengan Friction damper

Perilaku struktur selama pembebanan berlangsung, dan besarnya deformasi pada setiap tahap pembebanan. Dalam setiap proses pembebanan, elemen struktur akan mengalami deformasi. Nilai dalam proses pembebanan ini akan dicatat sehingga performa terbaik elemen struktur dapat direncanakan untuk dicapai.

\section{Hasil dan Analisa}

\section{Verifikasi Hasil FEM Dengan Hasil Eksperimen}

Sebelum studi parametrik dilakukan maka perlunya pembuktian (Verifikasi) hasil dari model finite elemen (ABAQUS). Untuk memvalidasi keakuratan hasil pemodelan dengan program bantu finite element, dilakukan perbandingan hasil kurva Momen - Rotasi dari hasil pemodelan setiap variasi pemodelan pada tesis ini (Tabel 4 dan 5).

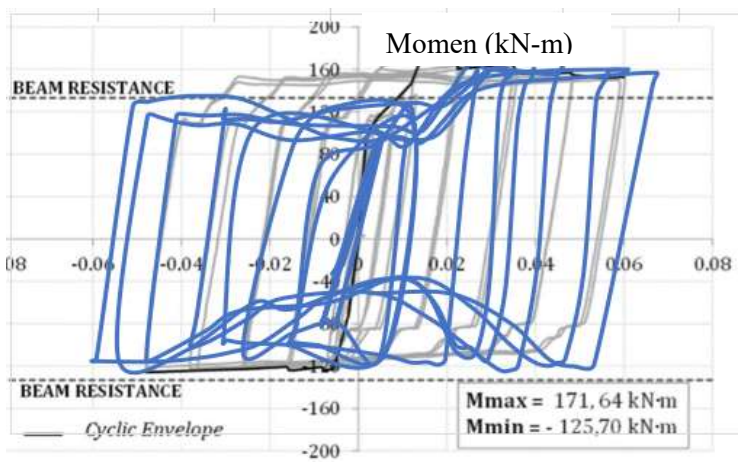

Gambar 8. Perbandingan Hyteresis Loop Eksperimen dengan Pemodelan Tipe TSJ-1

Sumber: Hasil Analisis

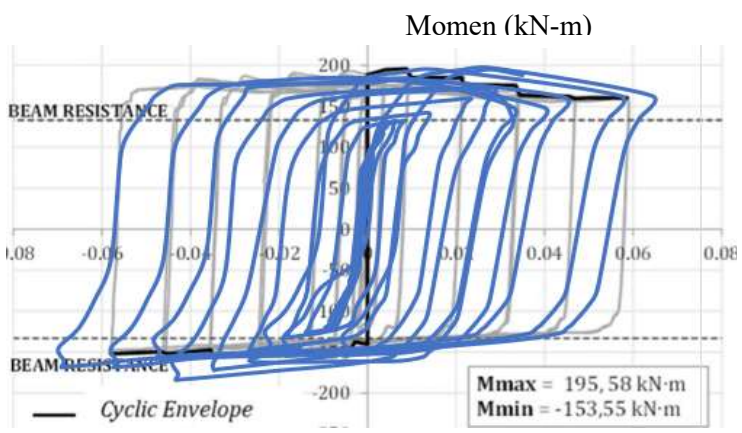

Gambar 9. Perbandingan Hyteresis Loop Eksperimen dengan Pemodelan Tipe TSJ-H

Sumber: Hasil Analisis

Gambar 9 menunjukkan distribusi tegangan yang terjadi akibat beban siklik pada model sambungan tipe TSJ-1 dengan step berturut - turut step 109, dan step 147. Nilai tegangan maksimum dari spesimen ini mencapai 397.864 $\mathrm{MPa}$ saat displacement mencapai $91.2731 \mathrm{~mm}$ yang terjadi pada pusat rotasi dari sambungan (gambar dengan lingkaran berwarna merah) pada step 147. 
Tabel 4. Verifikasi Variasi TSJ-1

\begin{tabular}{|c|c|c|c|}
\hline \multirow[b]{2}{*}{ No } & \multirow[b]{2}{*}{ Variasi } & \multicolumn{2}{|c|}{ Momen-Rotasi } \\
\hline & & $\begin{array}{l}\text { Mmax } \\
(\mathrm{KNm})\end{array}$ & $\theta(\mathrm{rad})$ \\
\hline 1 & Eksperimen TSJ-1 & 171.64 & 0.022 \\
\hline 2 & Pemodelan TSJ-1 & 163.20 & 0.060 \\
\hline & Selisih & 8.44 & -0.048 \\
\hline
\end{tabular}

Sumber: Hasil Analisis

Tabel 5. Verifikasi Variasi TSJ-1

\begin{tabular}{cccc}
\hline \multirow{2}{*}{ No } & \multirow{3}{*}{ Variasi } & \multicolumn{2}{c}{ Momen-Rotasi } \\
& & $(\mathrm{KNm})$ & $\Theta(\mathrm{rad})$ \\
\hline 1 & Eksperimen TSJ-H & 195.58 & 0.01 \\
2 & Pemodelan TSJ-H & 225.742 & 0.049 \\
\hline & Selisih & 30.1620 & -0.055 \\
\hline
\end{tabular}

Sumber: Hasil Analisis

\section{Distribusi Tegangan akibat Beban Siklik}

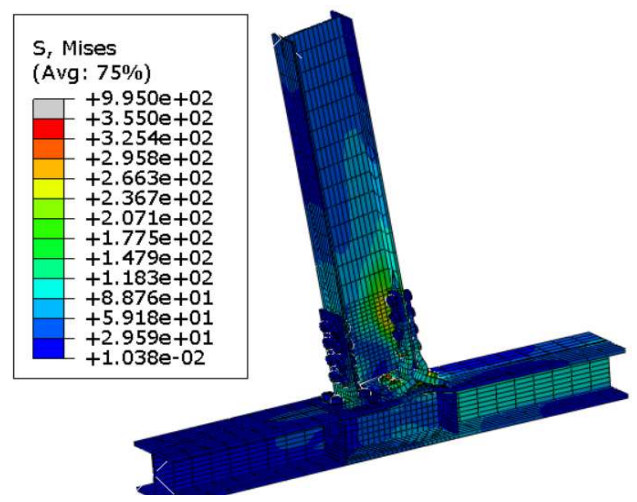

Gambar 10. Distribusi tegangan TSJ-1

Sumber: Hasil Analisis

Gambar 10 menunjukkan distribusi tegangan yang terjadi akibat beban siklik pada model sambungan tipe TSJ1 dengan step berturut - turut step 199, dan step 205. Nilai tegangan maksimum dari spesimen ini mencapai 419.8610 MPa saat displacement mencapai $94.7008 \mathrm{~mm}$ yang terjadi pada pusat rotasi dari sambungan (gambar dengan lingkaran berwarna merah) pada step 205 .

Gambar 11, menunjukkan distribusi tegangan dan mode kegagalan awal yang terjadi pada model sambungan tipe TSJ-3 terjadi pada L-Stub yang menempel pada web balok. Bagian yang mengalami leleh berikutnya adalah permukaan kontak antara L-Stub dan badan balok serta baut pengait keduanya.

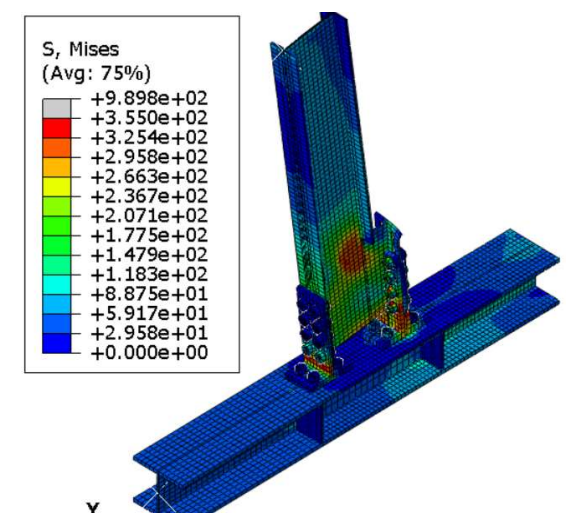

Gambar 10. Distribusi tegangan TSJ-H

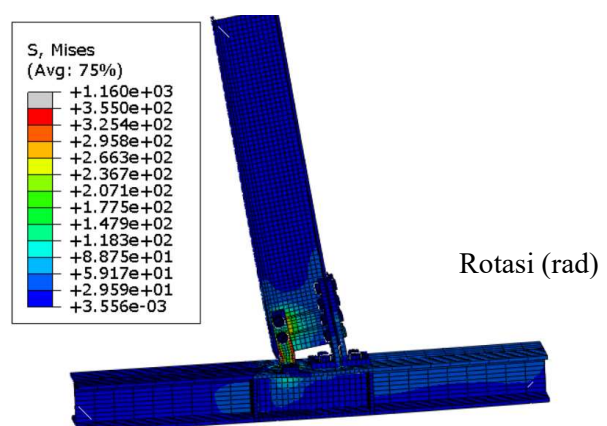

Gambar 11. Distribusi tegangan TSJ-3

Sumber: Hasil Analisis

Gambar 12, menunjukkan distribusi tegangan dan mode kegagalan yang terjadi pada model sambungan tipe TSJ-R. Bagian awal yang mengalami leleh terlebih dahulu adalah Haunch bagian yang menempel pada balok. Kemudian bagian yang lelh berikutnya adalah flange balok bagian friction damper yang kemudian diikuti oleh baut-baut pengait pada L-Stub dan Flange baloknya.

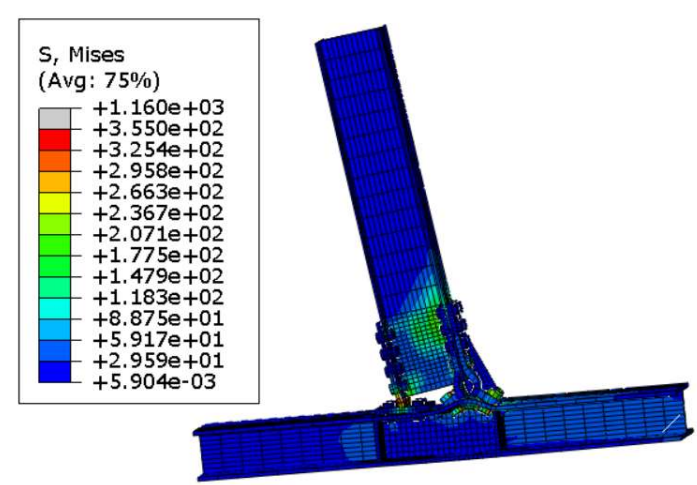

Gambar 12. Distribusi tegangan TSJ-R Sumber: Hasil Analisis 


\section{Daktilitas}

Faktor daktilitas struktur gedung $(\mu)$ adalah rasio antara simpangan ultimit dan simpangan pada saat terjadinya leleh pertama. Nilai daktilitas dari setiap spesimen perlu menjadi perhatian dalam mempertimbangkan pemilihan penggunaan metode yang tepat dalam penerapannya pada gedung bertingkat. Nilai daktilitas yang tinggi akan sangat terasa manfaatnya bila diterapkan pada gedung di daerah dengan nilai beban lateral yang tinggi. Hasil Analisa dari masing masing pemodelan dapat dilihat pada tabel 6 .

Tabel 6. Daktilitas

\begin{tabular}{clccc}
\hline \multirow{2}{*}{ No } & \multirow{2}{*}{ Spesimen } & \multicolumn{2}{c}{ Simpangan saat } & \multirow{2}{*}{ Daktilitas } \\
& & Leleh Pertama & Ultimate & \\
\hline 1 & TSJ-1 & 33.670 & 91.273 & 2.711 \\
2 & TSJ-H & 13.227 & 94.701 & 7.160 \\
3 & TSJ-3 & 23.339 & 95.096 & 2.075 \\
4 & TSJ-R & 34.6369 & 95.895 & 4.176 \\
\hline
\end{tabular}

Dari Tabel 6 terlihat bahwasannya tambahan haunch pada spesimen TSJ-H dan penggunaan Ribs pada pemodelan TSJ-R pada sambungan balok dan kolom mampu menambah nilai daktilitas bilamana diterapkan pada struktur baja.

\section{Envelope curve}

Envelope curve terdiri dari beban puncak siklus pertama dari masing-masing siklus pembebanan lateral bolak-balik. Displacement arah positif menghasilkan envelope curve positif sedangkan displacement negatif menghasilkan envelope curve negatif. Kurva hasil perbandingan beban dan displacement dapat dilihat pada Gambar 13. Hasil tersebut menunjukkan bahwa variasi TSJ-3 mengalami pencapaian beban lateral maksimum tekan dan tarik serta penurunan beban tekan dan tarik yang sama, bila dibandingkan variasi sambungan TSJ-R. Hal ini terjadi dikarenakan variasi sambungan TSJ-R mengalami retakan awal pada sayap bagian balok yang kemudian diteruskan dengan retakan yang terjadi pada $T$-Stub sehingga sampai pada titik terjadi buckling pada tiap siklus pembebanan secara berurutan. Berbeda dengan spesimen TSJ-3 yang tidak mengalami retak pada panel zone dikarenan adanya penambahan $L-S t u b$ Web yang digunakan sebagai pusat rotasi.

\section{Disipasi energi}

Grafik energi disipasi setiap siklus pembebanan disajikan pada Gambar 14 - 17. Grafik perbandingan energi disipasi variasi sambungan TSJ-3 dan TSJ-R terlihat pada setiap variasi cenderung meningkat setiap adanya peningkatan beban, tetapi untuk setiap siklus pengulangan pada setiap level beban yang sama besarnya energi disipasi cenderung menurun. Adapun energi disipasi atau hysteretic energy menggambarkan kemampuan spesimen untuk mendisipasikan beban yang bekerja pada benda uji tersebut. Besarnya energi disipasi dihitung berdasarkan besarnya luasan kurva yang dibentuk dari satu siklus lengkap (positif dan negatif). Besarnya energi disipasi dihitung berdasarkan pendekatan numerik dengan cara menghitung luasan tiap pias pada siklus positif dan negatif.

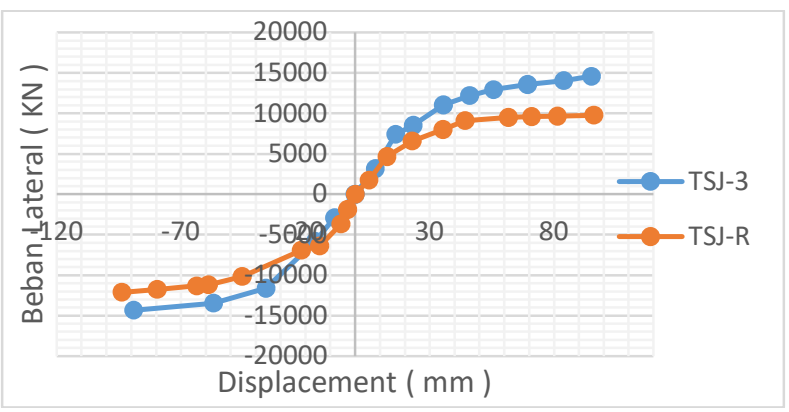

Gambar 13. Envelope curve TSJ-3 dan TSJ-R Sumber: Hasil Analisis

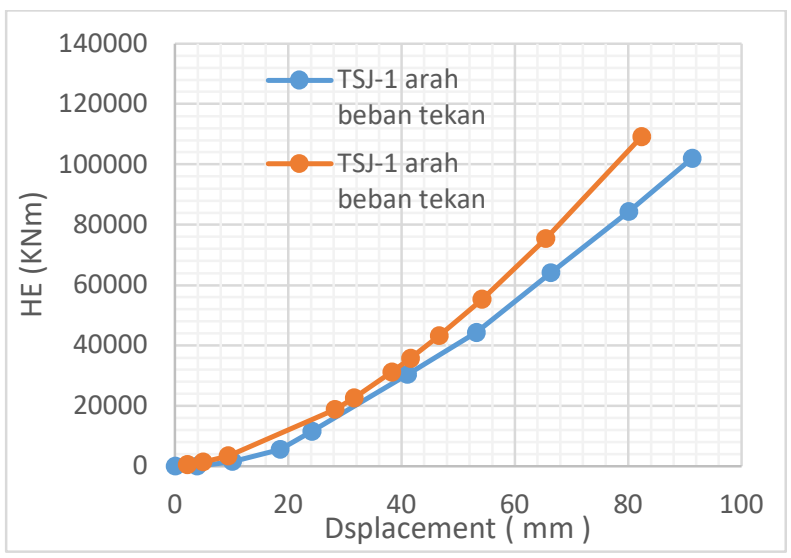

Gambar 14. Hysteretic curve TSJ-1 Sumber: Hasil Analisis

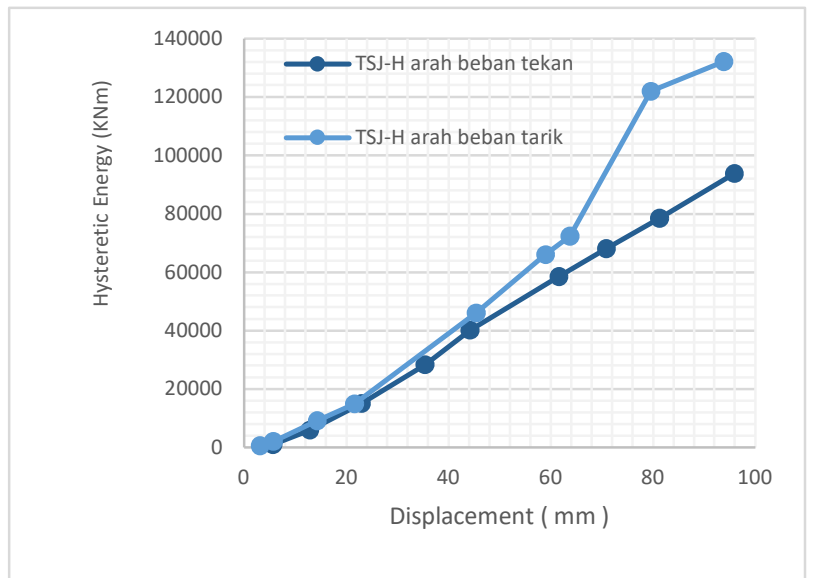

Gambar 15. Hysteretic curve TSJ-H Sumber: Hasil Analisis 


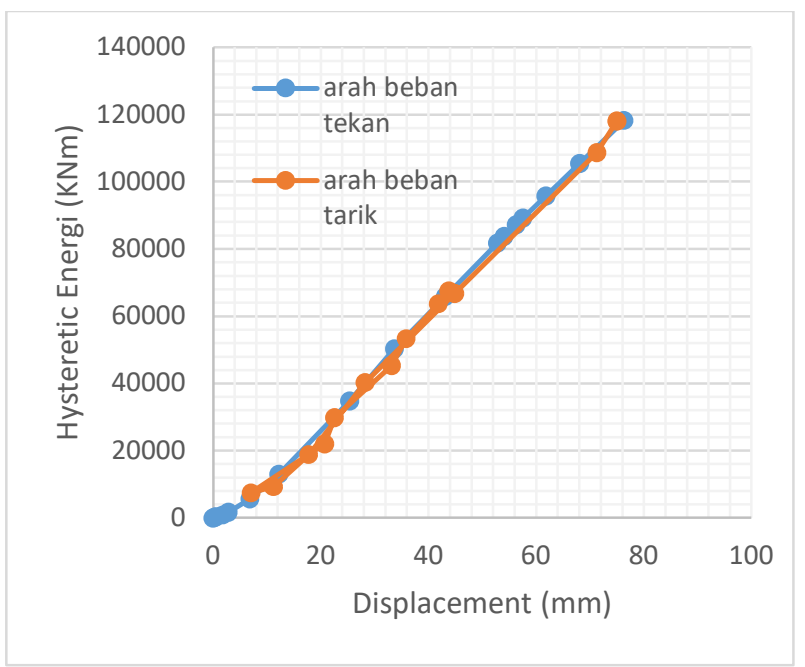

Gambar 16. Hysteretic curve TSJ-3

Sumber: Hasil Analisis

Pada Gambar 14 dan 15 menunjukkan bahwa spesimen variasi TSJ-H memiliki potential energy lebih besar dibandingkan dengan variasi TSJ-1. Model TSJ-R menghasilkan nilai Histeretic energi yang lebih besar bila dibandingkan dengan TSJ-3. Hal ini juga masih berkaitan dengan serapan energi yang dialami oleh setiap spesimen terhadap beban luar yang bekerja untuk setiap siklusnya untuk melihat kestabilan system struktur pada level perpindahan maksimum, ACI 374.1-05 mensyaratkan rasio energi disipasi pada siklus terakhir pada pembebanan siklik tidak boleh kurang dari 1/8 (0.125).

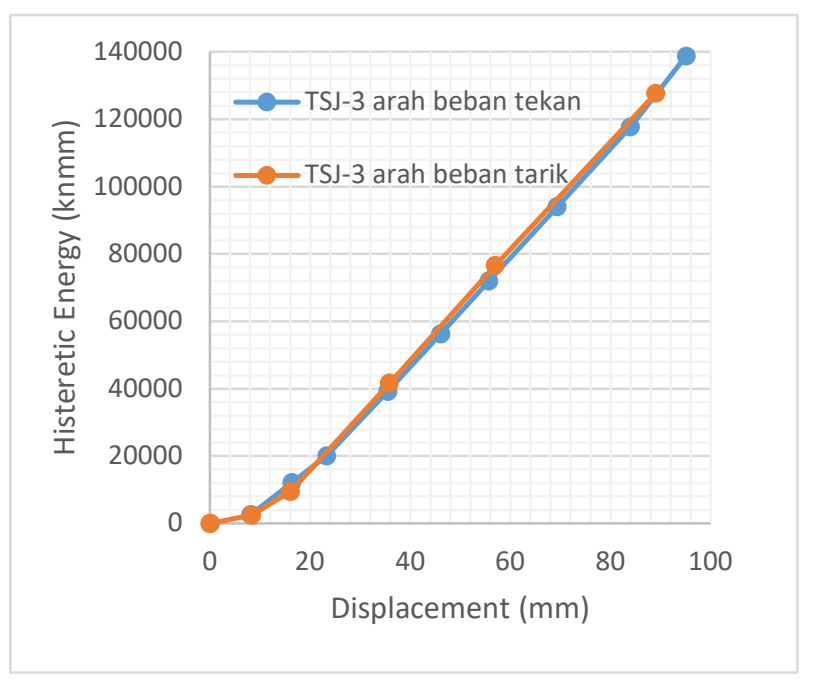

Gambar 17. Hysteretic curve TSJ-R

Sumber: Hasil Analisis

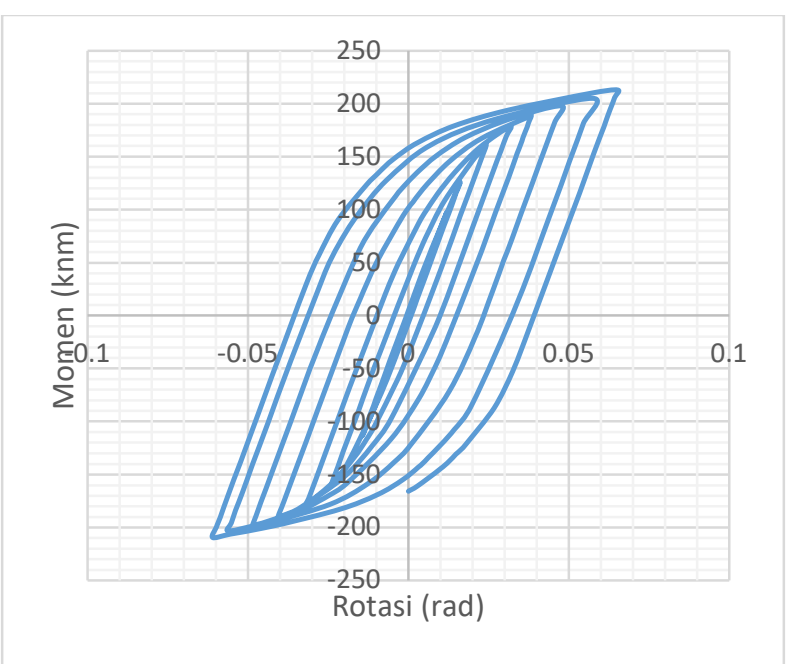

Gambar 18. Hyteresis Loop Eksperimen dengan Pemodelan Tipe TSJ-3

Sumber: Hasil Analisis

Pada gambar 18 dan 19 di atas menunjukkan bahwa spesimen variasi TSJ-R memiliki luasan kurva momen rotasi yang lebih besar bila dibandingkan dengan TSJ-3. Hal ini menyebabkan potential energy lebih besar dibandingkan dengan variasi TSJ-3. Penambahan Ribs pada sambungan balok - kolom juga menambah tingkat kekakuan dari model TSJ-R, hal ini terlihat dari rotasi yang dihasilkan kecil dengan nilai momen yang dihasilkan cukup tinggi. Kurva hysteresis loop antara TSJ-3 dan TSJ-R berbeda dikarenakan adanya awal terjadinya leleh hingga saat terjadinya kegagalan pada sambungan balok dan kolom.

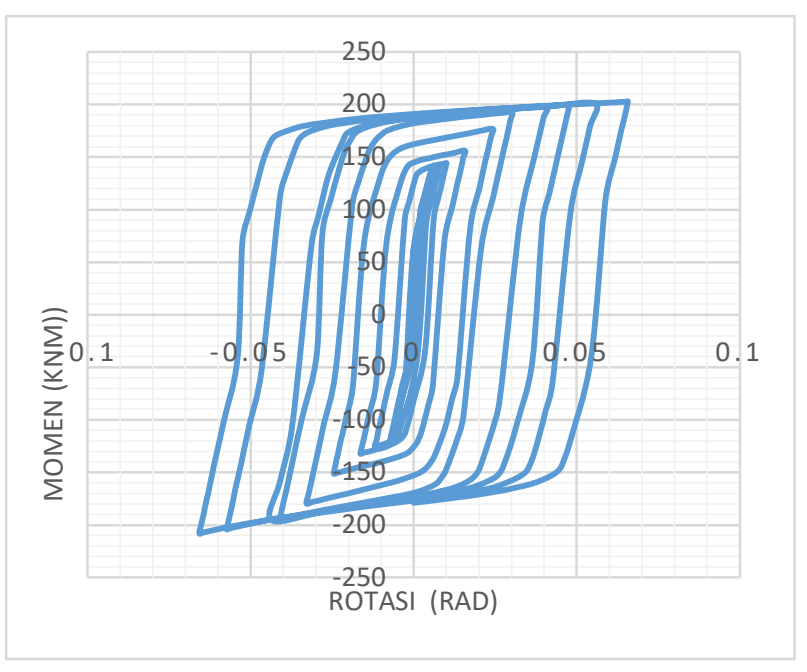

Gambar 19. Hyteresis Loop Eksperimen dengan Pemodelan Tipe TSJ-R

Sumber: Hasil Analisis 
Pada gambar 18 dan 19 di atas menunjukkan bahwa spesimen variasi TSJ-R memiliki luasan kurva momen rotasi yang lebih besar bila dibandingkan dengan TSJ-3. Hal ini menyebabkan potential energy lebih besar dibandingkan dengan variasi TSJ-3. Penambahan Ribs pada sambungan balok - kolom juga menambah tingkat kekakuan dari model TSJ-R, hal ini terlihat dari rotasi yang dihasilkan kecil dengan nilai momen yang dihasilkan cukup tinggi. Kurva hysteresis loop antara TSJ-3 dan TSJ-R berbeda dikarenakan adanya awal terjadinya leleh hingga saat terjadinya kegagalan pada sambungan balok dan kolom.

\section{Kesimpulan}

Berdasarkan pembahasan dari hasil analisa yang telah dilakukan, maka kesimpulan yang dapat diambil adalah sebagai berikut:

1. Perilaku yang dihasilkan dari spesimen variasi TSJ-1 dan TSJ-H untuk eksperimental dan ABAQUS memiliki mode kegagalan yang hampir sama. Dimana variasi TSJ1 terjadi kegagalan pada baut dan TSJ-H terjadi buckling pada panel zone dan patah pada baut. Namun jika dibandingkan dari segi performa, untuk distribusi tegangan variasi TSJ-H memiliki performa yang lebih baik dari variasi TSJ-1 karena dengan adanya penambahan haunch. Penambahan haunch akan mengalami tingkat kegagalan lebih sedikit dibandingkan tanpa haunch.

2. Adapun hasil dari beban lateral dan displacement, dimana beban lateral maksimal untuk spesimen TSJ-1 sebesar 111.78 KN pada displacement $91.2731 \mathrm{~mm}$, dan untuk spesimen TSJ-H sebesar $160.71 \mathrm{KN}$ pada displacement $94.70 \mathrm{~mm}, \mathrm{TSJ}-3$ sebesar $145.93 \mathrm{KN}$ pada displacement $95.096 \mathrm{~mm}$, dan untuk spesimen TSJ-R sebesar $97.74 \mathrm{KN}$ pada displacement $95.89 \mathrm{~mm}$. Ini menunjukkan bahwa kapasitas beban lateral spesimen TSJ-H lebih besar dari kapasitas beban spesimen untuk variasi yang lainnya. Dari hasil tersebut terlihat bahwa spesimen TSJ-H lebih daktail bila dibandingkan dengan spesimen lainnya.

3. Perbandingan energi disipasi pada spesimen TSJ-1, TSJH, TSJ-3, dan TSJ-R terlihat pada tiap spesimen cenderung meningkat setiap adanya penambahan beban. Pada semua spesimen yang dianalisis, spesimen TSJ-H memiliki potential energi lebih besar dibandingkan spesimen yang lainnya yakni sebesar $101679.81 \mathrm{KNmm}$ disusul dengan spesimen TSJ-3 sebesar 98769.8 KNmm, TSJ-R sebesar 93732.27 KNmm dan TSJ-1 sebesar 84361.66 $\mathrm{KNmm}$.

4. Dari semua variasi sambungan penggunaan Hauch pada variasi berpengaruh terhadap peningkatan performa dari sambungan balok dan kolom.

5. Nilai momen - rotasi pada eksperimental dan pemodelan pada setiap spesimen tidak jauh berbeda. Untuk spesimen
TSJ-1 sebesar 171.64 KNm, pada eksperimental momen sebesar $163.20 \mathrm{KNm}$ sehingga selisihnya sebesar 8.44 KNm. Untuk spesimen TSJ-H sebesar 225.742 KNm, pada eksperimental momen sebesar $195.58 \mathrm{KNm}$ sehingga selisihnya sebesar $30.1620 \mathrm{KNm}$. Untuk nilai rotasi pada spesimen TSJ-1 sebesar 0.022 rad dan pada eksperimental sebesar 0.065 rad dengan selisih sebesar 0.048 rad. Untuk nilai rotasi pada spesimen TSJ-H sebesar 0.049 rad dan pada eksperimental sebesar 0.01 rad dengan selisih sebesar $0.055 \mathrm{rad}$.

\section{Daftar Pustaka}

[1] Billina, "Studi Komparasi Isolasi Dasar High Damiping Rubber Bearing dan Friction Pendulum System pada Bangunan Beton Bertulang," J. Tek. Sipil, vol. 3, no. 3, 2017.

[2] R. L. M. D’Aniello, R. Tartaglia, S. Costanzo, "Seismic design of extended stiffened end-plate joints in the framework of Eurocodes," Seism. Des. Ext. stiffened end-plate joints Framew. Eurocodes, vol. 512-527, no. J. Constr. Steel Res. 128 (January 2017), 2017.

[3] A. B. Francavilla, M. Latour, V. Piluso, and G. Rizzano, "Design of full-strength full-ductility extended end-plate beam-to-column joints," J. Constr. Steel Res., vol. 148, pp. 77-96, 2018.

[4] M. E. Lemonis, "Steel moment resisting frames with both joint and beam dissipation zones," J. Constr. Steel Res., vol. 147, pp. 224-235, 2018.

[5] W. Adiyatma, I. Yasin, and Z. F. Haza, "Analisis Sambungan Gesesr Balok Baja dan Kolom Baja dengan Plat dan Baut Menggunakan Metode Elemen Hingga," vol. 82051, p. 82051.

[6] L. Dai, X. Zhao, and K. J. R. Rasmussen, "Cyclic performance of steel storage rack beam-to-upright bolted connections," J. Constr. Steel Res., vol. 148, pp. 28-48, 2018.

[7] R. Leon and J. Swanson, "Tests On Steel T-Stub Connections," Proc. 12th World Conf. Earthq. Eng. Auckland, New Zeal., no. 1, p. 8, 2000.

[8] P. Barata and A. Santiago, "Experimental Behaviour of T-Stub Joint Component at Elevated," no. April 2014, 2013.

[9] F. Danesh and E. Mohammadrezapour, "Experimental Investigation of T-Stub Link-to-Column Connections in Eccentrically Braced Frames," Int. J. Steel Struct., vol. 18, no. 2, pp. 486-495, 2018.

[10] K. Weynand and J.-P. Jaspart, "Design of Structural Steel Joints Design of Structural Steel Joints,” 2014.

[13] R. Soltani and D. E. Kerdal, "Behaviour of elementary bolted steel T-stub connections: An evaluation of EC3 
design procedure," Turkish J. Eng. Environ. Sci., vol. 35, no. 1, pp. 1-20, 2011.

[14] G. R. V. Piluso, "Random material variability effects on full-strength end-plate beam-to-column joints," , $J$. Constr. Steel Res. vol. 5, no. 658-666, 2007.

[15] M. Latour, V. Piluso, and G. Rizzano, "Experimenteal Analynis of Beam-to-Column Joints Equipped with Sprayed Aluminium Friction Dampers," , J. Constr. Steel Res. vol. 146, pp. 33-48, 2018. 
